\title{
A Comparison of the Early Responses to AIDS in the UK and the US
}

\section{Samuel Hallsor}

\section{University of Birmingham}

\section{Abstract}

The emergence of acquired immunodeficiency syndrome (AIDS) in the western world in the early 1980s marked the beginning of a new chapter in the history of communicable diseases. In the early stages of the epidemic, there was a distinct lack of knowledge about the aetiology and transmission of the disease, rendering control of the situation a practical impossibility. It was, however, clear that AIDS necessitated a definitive response from several sectors of society. Unfortunately, AIDS was associated with largely marginalized groups of society - such as homosexuals and injecting drug users - and, hence, almost every aspect of the response to AIDS was influenced by social and political perceptions of the disease and its victims. As the US and the UK have strong political and cultural links, in this essay I will compare the responses of these two nations to the AIDS epidemic at scientific, political, and community levels, as well as explore the interactions that occurred therein.

Keywords: AIDS; HIV; homosexuality; history

\section{INTRODUCTION}

While the exact origin of acquired immunodeficiency syndrome (AIDS) is still the subject of much controversy, the syndrome first became manifest clinically in Los Angeles. It was noticed that there was an unusually high prevalence of opportunistic infections among young and previously healthy homosexual males. ${ }^{1}$ In the following months, the number of reported cases of AIDS, which in its early days bore the stigmatic title "Gay Related Immune Deficiency" (GRID), ${ }^{2}$ began to rise across America $^{3}$ and news of this new infection spread across the Atlantic. The first reports of GRID in the UK appeared in The Lancet in late $1981^{4}$ and cases soon began to accumulate. ${ }^{5}$ It was clear from the statistics alone that AIDS had the potential to be a significant burden on health services in both nations and that an urgent response was required to reduce the impact of the burgeoning epidemic. The early 1980s also saw the emergence of the "New Right" movement under Margaret Thatcher's conservative government in the $\mathrm{UK}^{4}$ and the Ronald Reagan administration in the US, ${ }^{6}$ which was to have an undeniable influence on shaping the response to AIDS. This essay will compare the response of the UK and the US to AIDS at several levels: that of the gay community and their move towards advocacy and activism, that of the scientific community, and the later political response. The interactions, conflicts, and resolutions among these groups will also be examined.

\section{Homosexual community response}

Since the early cases of AIDS occurred predominantly among homosexual males, ${ }^{7}$ it is not surprising that the first response to the new epidemic was of self-help from within the gay community. Due to limited knowledge about the cause or transmission of the disease, it was primarily concerned with establishing support structures to cater to the needs of those suffering from AIDS. Established in New York in early 1982, the Gay Men's Health Crisis (GMHC) was the first organization of its kind in the $\mathrm{US}^{8}$ and pioneered the role of the voluntary sector in the response to AIDS. The first service provided by the GMHC was the Hotline, which began operations in 


\section{RES MEDICA \\ Journal of the Royal Medical Society \\ EST. 1957 Autumn 2017 VOL. 24 Issue 1 \\ doi:10.2218/resmedica.v24i1.1558}

HISTORICAL ARTICLE

May of the same year. ${ }^{8}$ Its aim was to answer questions from concerned individuals and their companions in times of fear and uncertainty. As the number of AIDS victims within the gay community rose, demand for care in the community increased and prompted a response from the GMHC. This response arrived in the form of a Buddy Programme. ${ }^{8}$ The establishment of the Buddy Programme marked the progression of the GMHC from remote to bedside provision of care - a move which was necessitated by the debilitating effects of the disease and the failure of healthcare organizations to provide adequate hospital care. Volunteers in the programme provided domiciliary services for bedbound people in the latter stages of the disease ${ }^{9}$ and fulfilled nursing roles in hospitals, as a significant proportion of the nursing staff now refused to work with AIDS patients due to fears of contagious spread. ${ }^{8}$

The growing impact of AIDS placed similar demands on the British gay community to care for its affected members. The Terry Higgins Trust (THT) is an organization with similar objectives to those of the GMHC and was established after the death of Terrence Higgins in July $1982 .{ }^{4}$ In contrast to their US counterparts, the trust originally set out with the sole aim of raising funds for research into GRID, but after significant organizational changes in 1983-4, it attained charity status ${ }^{10}$ and modified its role to involve community-based care for AIDS patients. ${ }^{4}$ Now operating under the more formal name of the Terrence Higgins Trust, 4 the organization adopted many strategies that were already being utilized by the GMHC. Towards the end of 1983, the THT operated an informal helpline offering information on AIDS and, in 1984, the trust established its own buddying scheme to provide social support to those affected by AIDS. ${ }^{4}$ However beneficial these social support structures might have been to patients and their loved ones, the prevalence of AIDS was still steadily rising ${ }^{3,5}$ and, in the absence of effective treatment, patients were faced with no other option than to accept the inevitability of death. ${ }^{11}$ In recognition of this dire situation, gay self-help organizations began to place greater emphasis on health education as a means of curbing the spread of AIDS. However, this move proved contentious as homosexuality had only recently been decriminalized in 1967 in the UK12 and many US states had yet to repeal their sodomy laws despite intense periods of civil rights activism. ${ }^{13,14}$. Some members of the homosexual community were critical of early health education efforts, viewing them as an encroachment upon their new and hard-earned freedom. ${ }^{4,9}$

For the GMHC, however, it was the discovery of the causative agent of AIDS in 1983 which prompted the development of a health education campaign. 8 The first GMHC leaflets detailing safe sex practices were published in the same year and were widely reproduced in the UK by the THT before the publication of their own literature in late $1983 .{ }^{4}$ Health education campaigns came to dominate the work of self-help organizations in both countries and very quickly gained a reputation for being sources of up-todate information on AIDS. For example, the US's GMHC was consulted by health organizations like the Centers for Disease Control (CDC) for assistance, 8 while in the UK, representatives from the THT met with the Chief Medical Officer (CMO) of the Department of Health and Social Services (DHSS) in 1983 to provide key policymakers with information on the AIDS epidemic. ${ }^{4}$ The efforts of the self-help organizations were beginning to attract support from other areas of society, most notably at the Conway Hall Conference in 1983. This was attended by figureheads from British and American gay voluntary organizations and eminent members of the scientific community, and serves as an example of early collaboration between these groups. ${ }^{4}$ The interest of the scientific community was clear, and it sought to provide answers to the many questions posed by the epidemic and apply scientific principles to bring it under control.

\section{Public response}

At this juncture, it is worth considering the response of the public to the emerging AIDS crisis, as the 


\section{RES MEDICA \\ Journal of the Royal Medical Society \\ EST. 1957 Autumn 2017 VOL. 24 Issue 1 \\ doi:10.2218/resmedica.v24i1.1558}

HISTORICAL ARTICLE

prevailing social climate certainly had an impact on the activities of the newly formed action groups and their ability to attract support. In the early days of the epidemic in the US, it was common for victims of AIDS to be blamed for their illness ${ }^{15}$ due to the widely held view that AIDS was a direct result of homosexual behaviour. ${ }^{16}$ AIDS was considered by many as an exclusively gay disease ${ }^{16}$ and there existed a popular viewpoint that the "general population" was not at risk. ${ }^{11}$ This inevitably led to further stigmatization of an already marginalized group. Also in the UK, reports of a "gay plague" were rife in the mainstream press, ${ }^{17}$ reflecting the attitudes of the British public towards the disease. ${ }^{4}$ This period of confusion and misinformation was perhaps indicative of the scientific community's inability to provide an adequate explanation for the unfolding events, which unfortunately resulted in the homosexual community becoming a focus of blame in times of great fear and uncertainty.

\section{Scientific response}

The scientific response to the AIDS epidemic can be divided into two broad categories: epidemiology and biomedicine. In the early stages of the AIDS crisis, epidemiological methods necessarily came to prominence and identified risk groups from the available data and case reports. It was realized that groups outside of the homosexual community, namely haemophiliacs, heroin users, and Haitians, were also at increased risk of AIDS. ${ }^{18}$ There were multiple implications: AIDS was not a homosexual disease, public health interventions could be more effectively targeted towards high prevalence groups, and hypotheses on the mode of transmission could be better informed and tested in the laboratory. Convinced that AIDS could be the clinical manifestation of a viral illness, two laboratories - the Pasteur Institute in Paris led by Luc Montagnier and National Institutes of Health in Bethesda, Maryland, headed by Robert Gallo - independently began work on proving this theory. ${ }^{19}$ In early 1983, human immunodeficiency virus (HIV) was first isolated by Luc Montagnier's team and breakthroughs made in the Gallo laboratory later in the same year provided further evidence that HIV was the cause of AIDS. ${ }^{19}$

The identification of a virus as the causative agent significantly changed the course of the subsequent scientific response to AIDS and gradually shifted the focus away from epidemiology. ${ }^{9}$ In terms of transmission, it marked a shift from the "who you are" stance of epidemiology to the "what you do" stance of the biomedical model. ${ }^{4}$ This supported the notion that heterosexual spread was entirely possible. This fear was realized in 1984, when the recently developed HIV enzyme-linked immunosorbent assay (ELISA) test confirmed that blood banks in the US were contaminated with the virus. ${ }^{2}$ The application of the biomedical model to AIDS significantly changed the frames of reference through which the disease was viewed and established a target for subsequent research on the development of effective treatments. Specific knowledge of the viral vector of AIDS transmission worked in tandem with the epidemiological construct of risk groups to guide public health campaigns towards high risk populations and behaviours. Modification of individual behavioural patterns was seen as the only effective means of controlling the epidemic in the US, thus moderation of high-risk behaviours became the focus of health education campaigns with their origins in the gay selfhelp movement. ${ }^{16}$

On a regional level, more drastic approaches to public health intervention were implemented. In a decision evocative of John Snow's removal of the Broad Street pump handle, the closure of gay bathhouses was enforced in San Francisco in 1984 with the intention of limiting the transmission of AIDS via unprotected sexual intercourse with multiple partners. ${ }^{2}$ This measure proved ineffective, however, because the majority of frequent bathhouse users were already affected at the time of implementation. ${ }^{9}$ Furthermore, bathhouse attendance began to diminish in the wake of the AIDS epidemic, ${ }^{16}$ which can perhaps be partly attributed to the success of health education campaigns, particularly those directed towards the 


\section{RES MEDICA \\ Journal of the Royal Medical Society \\ EST. 1957 Autumn 2017 VOL. 24 Issue 1 \\ doi:10.2218/resmedica.v24i1.1558}

HISTORICAL ARTICLE

homosexual community. In the UK, similar health education campaigns were at the centre of public health efforts to prevent AIDS, but still fell within the remit of voluntary organisations like the THT, whose efforts were focused predominantly on the homosexual population. The CMO of the DHSS had formally recognised AIDS as a major health issue in 1984 and was determined that science should play a key role in controlling the epidemic, a belief which led him to establish the Expert Advisory Group on AIDS (EAGA) in 1985.4 The EAGA comprised exclusively of members of the biomedical community and certainly helped to assert the authority of science in the AIDS policy-making arena. ${ }^{4}$ The scientific and voluntary organizations in both the UK and the US were still operating at a sub-governmental level although it was clear that support was needed from a higher political position to sanction the power and resources required for the continuation of AIDS prevention efforts.

\section{Move to advocacy}

By 1985, the role of many of these organizations had expanded to involve advocacy and politics, with the aim of securing much needed governmental support. It was the foundation of the Public Policy Department in 1986 which marked the beginnings of the role of the GMHC in government advocacy. ${ }^{8}$ At the time, the Reagan administration had been criticized by homosexual communities for its lack of interest in the AIDS issue ${ }^{2}$ and not without reason. The federal government had controversially decided to oppose requests from congress for extra funding to cope with the ever increasing workload with which public health institutions were being burdened. ${ }^{16}$ The Public Policy Department lobbied the government to increase funding for AIDS research and the implementation of prevention programmes ${ }^{8}$ and were largely supported in their aims by public health organizations who were simultaneously requesting additional funding to deal with the ever growing magnitude of the epidemic. ${ }^{16}$ Organizations in the UK were developing similar advocacy roles to their US counterparts, but the THT in particular had had a political agenda since its reorganization in 1983. The trust sought to forge itself a public role to draw attention to the political dangers posed by the AIDS epidemic in response to the absence of government support. ${ }^{4}$ Following a meeting with THT representatives in 1984, the CMO recognized the importance of the trust's contribution to AIDS policy making and directed substantial departmental funding into supporting its activities. ${ }^{4}$ Although the establishment of the EAGA in 1985 substantially reduced the share of the power previously held in the AIDS policy-making arena by the THT, both organizations were liberal in terms of political orientation, ${ }^{4}$ so the interests of the homosexual population were upheld, to an extent, at a departmental level. While such activities undoubtedly came to the attention of the politicians of the UK and the US, it was for different reasons that the apathy of the rightwing governments was overturned.

\section{Political response}

The social construction of AIDS, namely the separation of victims into "innocent" and "guilty" groups ${ }^{2}$ had a significant influence on the response, or lack thereof, at the political level. In accordance with the conservative doctrine of the republican party, the Reagan administration in the US advocated personal responsibility in relation to health. ${ }^{2}$ The administration was thus disinclined to help the already marginalized homosexual and drug-using communities, whose infection with AIDS was widely considered to be a direct consequence of their behaviour. ${ }^{2}$ In an analysis of the federal government response conducted by the Office of Technology Assessment (OTA), it was found that inadequate funding was provided for AIDS research and education and it was further suggested that the reason for this was homophobic attitudes which were endemic in the political community. ${ }^{16}$ When AIDS was detected in haemophiliacs, surgical patients, and babies of infected mothers, ${ }^{2}$ it was clear that the disease no longer claimed its victims exclusively from stigmatized groups of society, essentially forcing the government to take action and 


\section{RES MEDICA \\ Journal of the Royal Medical Society \\ EST. 1957 Autumn 2017 VOL. 24 Issue 1 \\ doi:10.2218/resmedica.v24i1.1558}

HISTORICAL ARTICLE

protect the interests of these "innocent" victims of the epidemic. One element of the AIDS prevention policy was education, the focus of which was indicative of the socially conservative sentiments of the policy makers. Government health education campaigns aimed purely to deliver the facts about AIDS and were not specifically directed towards the homosexual community, instead insisting that educational activities and materials should emphasize abstinence from homosexual activities. ${ }^{20}$ In 1985, with the AIDS issue firmly on the government's agenda, funding for AIDS research received a much-needed boost 21 which, while critical to the AIDS prevention efforts, came four years after the first cases of the disease were reported. This delay was recognized by the OTA, who condemned the slow government response and asserted that bureaucratic institutions were to blame. ${ }^{16} \mathrm{~A}$ similar degree of latency was also present in the UK government's response to AIDS. However, in contrast to the conservative attitudes which characterized the US response to the crisis, it was the predominantly liberal civil service who engineered the government response to AIDS in the UK. The epidemic was eventually defined as a high priority in $1986^{4}$ and, in the flurry of political activity that ensued, an emergency commons debate was held in which the Secretary of State for Health declared that information was the only vaccine, ${ }^{4}$ thus emphasizing the importance of education in the fight against AIDS. A cabinet committee was convened on the AIDS issue to oversee the formulation of the proposed national education campaign and to consider other more practical public health measures such as the distribution of free condoms. ${ }^{4}$ The EAGA held a position of influence in the AIDS policy-making community. They had a key role in ensuring that the objectives of various health education campaigns, which began later in 1986, were liberally orientated4 and focused on harm minimization rather than limitation of high-risk behaviours, for example condom use for anal intercourse. ${ }^{4}$ As in the US, the general population was the target of the governmentsupported health education campaign, albeit for entirely different reasons. Whereas the conservative American government was determined to maintain the focus on "innocent" victims of AIDS, many policy makers in the UK feared that aiming a campaign at the homosexual community could be criticized as homophobic and may trigger a backlash from the gay community, ${ }^{4}$ although some conservative ministers still voiced concerns of promoting immoral behaviours in parliamentary debates. ${ }^{22}$ For many communities affected by AIDS, government intervention was still seen as inadequate because AIDS patients were still dying in large numbers in the absence of effective treatments. ${ }^{3,5}$ Frustrations about the apparent government inactivity peaked in the US in 1987, leading a group of activists in New York to form the AIDS Coalition To Unleash Power (ACT UP), ${ }^{23}$ an activist organization which listed "the establishment of a coordinated, comprehensive and compassionate national policy on AIDS" among their demands. ${ }^{24}$ The first ACT UP demonstration took place on Wall Street in 1987 and, in the same year, the coalition arranged a march on Washington, where an international conference on AIDS was being held. ${ }^{25}$ The demonstration succeeded in attracting significant media attention and clearly indicated, in the US at least, that activists from within the gay self-help community were willing to assume a more militant role to achieve their aims. On the other hand, the UK saw no such activist response, although some prominent members of gay self-help organizations spoke out in support of the ACT UP protests in the US and argued that activism should be encouraged as part of the response to AIDS in the UK. ${ }^{26}$

\section{Conclusion}

The AIDS crisis demanded action from several sectors of British and American society and while many similarities can be observed in their responses, important differences were also apparent. Similarities were commonplace among the scientific and homosexual communities in both nations, whose objectives were ultimately driven by necessity and thereby transcended political opinion. The possibility 
of a prompt, unified response was marred by governmental sluggishness as politicians became embroiled in the socio-political implications of intervening in an issue which predominantly affected marginalized groups of society. Aside from common delay in political intervention, the responses to AIDS in the UK and the US at a political level were markedly different, perhaps as a result of the differing political stances of the bureaucratic institutions underpinning the key policy-making groups. The Reagan administration sustained its typically socially conservative attitudes whereas the UK government opted for a more liberal approach to managing the AIDS crisis despite its conservative status.

At a time of great uncertainty and moral confusion, these early responses to AIDS set the tone for future attempts to tackle the crisis. While the advent of highly active antiretroviral therapy (HAART) has transformed AIDS from a terminal diagnosis to a chronic manageable condition, sufferers are still often the victims of stigmatization and many of the moral controversies arising from the initial responses to the AIDS epidemic have been reawakened by the current debate about the provision of pre-exposure prophylaxis.

\section{Acknowledgements}

I would like to thank Dr J Reinarz for his supervision when writing this article and for allowing me access to his personal collection of books. I would also like to thank the staff at the University of Birmingham Library Service for their help in locating copies of some of the more difficult to find books I refer to in this article.

\section{Competing Interest and Funding}

Nothing to declare

\section{What is known already:}

- The AIDS epidemic first emerged in the 1980s and has since spread to affect millions of people worldwide

- Early cases of AIDS were predominantly found amongst homosexual males

- Stigma towards the homosexual community significantly influenced the early response to AIDS

\section{What this study adds:}

- Direct and details comparison of the responses of the UK and USA to the emerging AIDS crisis

- Responses from the homosexual and scientific communities were driven by necessity and often saw close collaboration

- Governmental responses in the UK and the USA were delayed by negative socio-political perceptions of affected groups

- The governmental response in the UK was far more liberal than the governmental response in the USA. 


\section{REFERENCES}

1. Centers for Disease Control. Pneumocystis pneumonia. MMWR Morb Mortal Wkly Rep. 1981;30(21):250-2.

2. Byrne JP. Encyclopedia of Pestilence, Pandemics, and Plagues. Volume 1, A-M. Westport, CT, USA: Greenwood Press; 2008.

3. Centers for Disease Control and Prevention. HIV and AIDS-United States, 1981-2000. MMWR Morb Mortal Wkly Rep. 2001;50(21):430-4.

4. Berridge V. AIDS in the UK: The Making of Policy, 1981-1994. Oxford, UK: Oxford University Press; 1996.

5. Select Committee on HIV and AIDs in the United Kingdom. No Vaccine, No Cure: HIV and AIDS in the United Kingdom. London, UK: The Stationery Office; 2011.

6. History. The 1980s. History website. http://www.history.com/topics/1980s (accessed 8 July 2016).

7. Osmond DH. Epidemiology of HIV/AIDS in the United States. 2003.

http://hivinsite.ucsf.edu/InSite?page=kb-01-03\#S1.2X (accessed 8 July 2016).

8. The New York Public Library. Gay Men's Health Crisis records. The New York Public Library Archives $\&$ Manuscripts website.

http://archives.nypl.org/mss/1126 (accessed 8 July 2016).

9. Shilts R. And the Band Played On: Politics, People and the AIDS Epidemic. London, UK: Souvenir Press; 2011.

10. Terrence Higgins Trust. How it all Began.

Terrence Higgins Turst website.

http://www.tht.org.uk/our-charity/Our-work/Ourhistory/How-it-all-began (accessed 8 July 2016).

11. Hilts PJ. Protecting America's Health: The FDA, Business, and One Hundred Years of Regulation.
Chapel Hill, NC, USA: University of North Carolina Press; 2004. pp. 237, 241.

12. Sexual Offences Act 1967 (Chapter 60). London, UK: Her Majesty’s Stationery Office; 1967.

13. Head T. Sodomy Laws in the United States: A Short History. 2016. About.com website. http://web.archive.org/web/20170212222953/http://civ illiberty.about.com/od/gendersexuality/tp/SodomyLaws-History-United-States-Timeline.htm (accessed 6 August 2017).

14. Head T. The American Gay Rights Movement: A Short History. 2016. About.com website. https://web.archive.org/web/20170127011454/http://ci villiberty.about.com/od/gendersexuality/tp/HistoryGay-Rights-Movement.htm (accessed 6 August 2017).

15. Rosenberg CE. Explaining Epidemics and Other Studies in the History of Medicine. Cambridge, UK: Cambridge University Press; 1992. p. 287.

16. Brandt AM. No Magic Bullet: A Social History of Venereal Disease in the United States Since 1880 with a New Chapter on AIDS. New York, NY, USA: Oxford University Press; 1987. pp. 99-198.

17. Garfield S. The End of Innocence: Britain in the Time of AIDS. London, UK: Faber \& Faber; 1995. pp. $41-4$.

18. Grmek MD, Maulitz RC, Duffin J. History of AIDS: Emergence and Origin of a Modern Pandemic. Princeton, NJ, USA: Princeton University Press; 1990. p. 31.

19. Gallo RC, Montagnier L. The discovery of HIV as the cause of AIDS. N Engl J Med. 2003;349(24):22835. DOI: 10.1056/NEJMp038194.

20. United States National Library of Medicine. Surviving and Thriving: AIDS, Politics and Culture. Safer Sex Comix \#8, 1987. 2013. http://www.nlm.nih.gov/exhibition/survivingandthrivin g/digitalgallery/detail-safersexcomix.html (accessed 8 July 2016). 
21. HIV.gov. A Timeline of HIV and AIDS. HIV.gov website. https://www.hiv.gov/hivbasics/overview/history/hiv-and-aids-timeline (accessed 8 July 2016).

22. TheyWorkForYou. AIDS: Oral Answers to Questions - Social Services - in the House of Commons at 12:00 am on 10th March 1987.

TheyWorkForYou website. https://www.theyworkforyou.com/debates/?id=19870310a.139.4\&s=speaker\%3A22552+speaker\%3A2255 2+speaker\%3A22552 (accessed 6 December 2016).

23. The New York Public Library. ACT UP New York records. The New York Public Library Archives \& Manuscripts website. http://archives.nypl.org/mss/10 (accessed 8 July 2016).
24. AIDS Coalition To Unleash Power. Flyer of the first ACT UP action March 24, 1987, Wall Street, New York City. AIDS Coalition to Unleash Power website. http://www.actupny.org/documents/1stFlyer.html (accessed 8 July 2016).

25. International AIDS Society. History of the IAS. Episode 1. International AIDS Society website. http://www.iasociety.org/Who-we-are/About-theIAS/25th-anniversary-of-the-IAS/Episode-1 (accessed 8 July 2016).

26. Carter E, Watney S. Taking Liberties: AIDS and Cultural Politics. London, UK: Serpent's Tail; 1989. p. 109. 